\title{
Impact of Exports on Economic Growth in the Non-Oil Sector in the Republic of Congo
}

\author{
Ossou Ndzila Fred Nelson ${ }^{1}$, Ossala Sonia Gladice ${ }^{2}$, Bambi Prince Dorian Rivel ${ }^{3} \&$ Ying Yirong $^{4}$ \\ ${ }^{1} \mathrm{Ph} . D$. Student in Finance at Shanghai University, Shanghai, China \\ ${ }^{2}$ Student of Economics at Marien Ngouabi University, Republic of the Congo \\ ${ }^{3}$ Ph.D. Student in Finance at Shanghai University, Shanghai, China \\ ${ }^{4}$ Professor in College of Economics, Shanghai University, Shanghai, China \\ Correspondance: Ossou Ndzila Fred Nelson, School of Economics, Shanghai University, China. Tel: \\ 86-136-7158-9407. E-mail: ossoundzila@ gmail.com
}

Received: January 15,2020

Accepted: January 29, 2020

Online Published: February 18, 2020

doi:10.5539/ijef.v12n3p46

URL: https://doi.org/10.5539/ijef.v12n3p46

\begin{abstract}
The purpose of this research was to analyze the impact of exports on the economic growth in the non-oil sector in the Republic of the Congo over the period of 1985 to 2015. Two approaches are used to achieve this study goal: the descriptive approach and the econometric approach. The results of our study show that non-oil exports have a negative effect on economic growth. Following these results, some recommendations are made to improve the contribution of exports to economic growth.
\end{abstract}

Keywords: exports, economic growth, non-oil sector

\section{Introduction}

\subsection{Background and Justification}

Exports are regarded as macroeconomic aggregates that are relevant enough to judge the strength of an economy. For capitalist economies, economic growth is seen as a necessary and sufficient weapon for the development of countries. This obsession remains forever in the minds of governments in all countries of the world. In fact, global growth increased slightly, from $2.4 \%$ to $2.6 \%$ between the years 2013-2014, reflecting the positive growth recorded since 2011 by most developed economies. At the world level, exports increased from $5.2 \%$ to $6.4 \%$ between the years 1985 and 1986, then a decline of 8.5\% against 7\% during the period of 1988 to 1989. From 2011 to 2014 exports were $6.9 \%$ against $3.3 \%$ (BEAC, 2014).

In the 1980s, the Republic of Congo experienced a growth rate of 5\%, one of the highest rates in Africa. The strong growth in oil revenues has enabled Congo to finance large-scale development projects. Subsequently, the fall in crude oil prices halved GNP and the 50\% devaluation of the CFA franc in 1994 caused a record rate of inflation of $61 \%$ in the same year.

During this period, income from foreign trade was small and offered little opportunity to effectively replace imports with home country products. Trade policy at that time was characterized above all by strong tariff and non-tariff protection, which could not weaken the growing industries that benefited from it without achieving the level of efficiency and expected competitiveness. Hence the year 1973 marks the discovery of oil, exports have taken an important part in the foreign trade of Congo Brazzaville.

The Republic of Congo, an oil-producing and exporting country, has lagged behind some non-oil countries in the black continent in terms of GDP per capita, as well as infant mortality, life expectancy, and so on. Thus, 50\% of the population lives on less than a dollar a day today and access to drinking water and electricity is still difficult. The country is sinking into debt, the level of poverty is rising and the environment continues to deteriorate, threatening the achievement of sustainable growth.

During the period 1990-1997, the average growth rate per inhabitant was negative with $-1.82 \%$. The real growth of the economy has been insufficient due to the recession of the non-oil sector. This weak performance can be explained internally, by the existence of an incoherent macroeconomic policy, by the difficulties of adapting to the transition from a socialist-type directed economy to a policy of openness based on liberalism. 
At the external level, we can also note the decline in world prices of certain commodities, the deterioration of the terms of trade, and the decline in demand for non-oil export products which have had an adverse effect on the economy.

The Republic of Congo currently faces enormous challenges in mobilizing the financial resources needed to build infrastructure, pay down debt and reduce poverty. After three years of weak economic growth, the Congo achieved growth in 2014. It was $6.4 \%$, which is a clear improvement over the average annual growth rate of $3.5 \%$ achieved between the years 2011 and 2013. It was driven by the resumption of oil production and continued public investment in infrastructure (rapport de suivi sur la situation économique et financière, 2015).

From 2014, following the decline of oil barrel the prices, this situation deteriorated until 2017, the Republic of the Congo recorded a negative growth rate of $-1.7 \%$ which resulted in an unemployment rate of $53 \%$ and the difficulties of the social protection system led to the amplification of poverty. Following this, the Congolese government set up diversification policies in order to increase the range of exported products and reduce the share of oil in exports.

\section{- Interest}

Exports are an important outcome for the development of a country and can promote wealth creation and poverty reduction. So the choice of this subject is twofold:

Firstly: it is the current nature of the subject, since the economic crisis due to the drop in the price of a barrel of oil on the world market. The Congo continues to implement the strategies of diversification of its products to be exported in order to gain the ability to withstand exogenous shocks.

Secondly: The scarcity of recent studies for the case of Congo and finally the obtained results will make it possible to formulate recommendations in order to suggest solutions for Congo's economic diversification.

\subsection{Problematic}

The Republic of Congo, like most African countries in the south of the Sahara, after its independence, had first proposed a policy of import substitution that unfortunately showed its inadequacies. Secondly, it moved towards an export promotion strategy towards the year 1994, that is to say, a decade after the new policy of openness proposed by the World Bank and the International Monetary Fund (IMF) in 1980, in the context of Structural Adjustment Programs (SAPs). The main export products at the time were timber, agricultural products, sugar, and potash, which were the main sources of foreign exchange but could not cover more than $60 \%$ of imports. Priority was, however, given to wood sector exports, which accounted for $50 \%$ of total exports. The preponderance of mining products, in this case, oil in foreign trade, has been affirmed since 1973.

\section{- Research questions}

Two questions are the subjects of this study:

- What is the evolution of exports and economic growth in Congo?

- What is the impact of exports on economic growth in Congo?

\subsection{Objectives of the Study}

The main objective of this research is to analyze the impact of exports on economic growth in Congo in the non-oil sector, and more specifically, it is to:

- Analyze the evolution of exports and growth in Congo.

- Determine the impact of exports on growth in Congo.

\subsection{Research Hypothesis}

- Exports and growth are evolving over time.

- Exports have a positive influence on economic growth.

\section{Review of the Literature}

\subsection{Empirical Work Highlighting the Positive Relationship between Exports and Growth}

BY examining the correlation between economic growth and exports, Michaely (1977) and Balassa (1978) used the Spearman rank correlation coefficient for this purpose. Indeed, for a first set of "undeveloped" countries over the period of 1950-1973, Michaely finds a coefficient of 0.38, significant at the $1 \%$ threshold. For another group of 23 income countries (constant prices in the year 1972) over $\$ 300$, he finds a coefficient of 0.523 , for the non-developed countries in this sample, he finds a coefficient almost zero and concludes that economic growth 
of a country is impacted by exports only from an income threshold.

Balassa (1978) for his part, studied in 11 countries over the period 1960-1973, he uses a calculation of the coefficient of correlation between the growth rate of exports and the growth rate of GNP. He reaches to the same conclusion about the existence of a relationship between growth and exports. To further clarify these ideas, Balassa borrows the methodology of Michalopoulos and Jay (1973) based on panel data. He confirms the decisive role of exports in the development process and advises developing countries to adopt policies geared towards improving their exports.

Syrquin and Chenery (1989), two economists at the World Bank, conducted an analysis by observing the share of exports in the GDP of various countries after an adjustment program, taking into account the size of the country and the specialization of the countries' exports. For them, the results show that the growth rate is higher for the opened countries in the following sub-group: commodity exporters, major exporters of primary products, small exporters of manufactures, major exporters of manufactures. According to Syrquin and Chenery, the growth gain due to the outward opening is between $0.2 \%$ and $1.4 \%$.

Subsequently, they analyzed the relationship between growth rate and exports in developing countries. They drew conclusions that there is a positive relationship between exports and growth and they have proved that the correlation is more distinguishable in a subsample of middle-income countries. Their aim was to show the superiority, in terms of growth, of an export promotion policy in relation to an import substitution policy.

As far as Akilou (2009), studying the effect of export volatility on Togo's economic growth from 1960 to 2005 finds that, in the short term, exports have a positive effect on economic growth at the threshold of $10 \%$.

Saminira and Adamson (2013) examined the relationship between exports and economic growth in Madagascar. Econometric analysis over the period under review shows that an increase in exports of $10 \%$ results in the economic growth of $0.95 \%$.

However, other recent empirical works have put into perspective the findings on the effect of commodity exports on growth.

Indeed, Snyder (2006) and Brunnschweiler (2008) have shown that the effect of commodity exports on growth is not necessarily negative, but depends on the quality of institutions. Thus, while countries have developed good institutions, commodity dependence facilitates growth. In addition, Stijns (2005), Brunnschweiler and Bulte (2009), and Lederman and Maloney (2008) suggest that regression results on growth that show a negative effect of commodities are not robust to changes in model specification and or the definition of commodity dependency.

\subsection{Empirical Work Highlighting the Negative Relationship between Exports and Growth}

Similarly, Subasat (2002) analyzed the empirical linkages between exports and economic growth for developing countries. The analysis has shown that more export-oriented countries, such as middle-income countries, are seeing their economic growth grow faster than relatively weaker countries in terms of exports. The study also showed that export promotion does not necessarily have significant impacts on economic growth, especially in low-income countries.

By making estimates on cross-sectional data to overcome the drawbacks associated with the Balassa methodology with a set of 55 developing countries over the period of 1960-1977, Tyler (1981) confirms the role played by exports in growth and asserts that the countries that neglect the export sector should expect a low rate of economic growth.

\section{Methodology}

For set objectives to be achieved, two approaches have been adopted: A descriptive approach and an econometric approach.

The descriptive approach will enable us to reach our first objective, which is to make a comparative analysis of the evolution of exports and economic growth in Congo. This analysis was illustrated from the various Figures to understand the relationship between economic growth and exports between 1985 and 2015.

To achieve the second objective, which is to analyze the impact of exports on economic growth between 1985 and 2015, the econometric approach was adopted.

\subsection{Model Specification}

In the case of this study, we will use exports, active population gross fixed capital formation and we will add two variables that are: the term of the exchange and the degree of commercial openness. The addition of these variables is justified by the fact that they are likely to act or promote economic growth in Congo. Note that the 
study of temporal time series requires prior knowledge of the behavior of its stochastic characteristics (its expectation, its variance, and its covariance), in order to realize whether it is stationary or not. The constancy of the value of its characteristics over time proves the existence of stationarity of the considered time series, whereas if it is modified in time, the series considered is non-stationary. In the econometric literature, several statistical tests are used to determine the degree of integration of variables. The tests that will be used in this study are the Augmented Dickey-Fuller (ADF) test, that of Phillips-Perron (PP). Once the series integration order is known, the next step will be to examine the possible presence of the cointegration relationship that may exist in the long term between the variables.

Hence the equation of the model appears as follows:

$$
L G D P=f(L E X P, L P O P, L G F C F)
$$

Formally, our model will be written as follows:

$$
L G D P_{i t}=\alpha_{i}+a_{1} L E X P_{i t}+a_{2} L P O P_{i t}+a_{3} L_{G F C F}+a_{4} L E X C H t_{i t}+a_{5} L O P E N d_{i t}
$$

With

LGDPno: $\log$ of the non-oil gross domestic product;

LEXPno: the logarithm of non-oil exports;

LPOP: the log of the population;

LGFCF: the logarithm of gross fixed capital formation

LEXCt: the logarithm of the exchange term

LOPENd: the logarithm of the degree of the opening;

$\mathrm{a}_{\mathrm{i}}$ : denotes the coefficients of the variables to be estimated;

$\alpha_{\mathrm{i}}$ : the specific effect of controlling the unobservable differences that exist between statistical units.

\subsection{The Link Between the Endogenous Variable and the Exogenous Variables}

This section pinpoints the theoretical and empirical relation that exists between the endogenous variable and the different exogenous variables.

\section{- Exports}

In the context of this study, exports will not be disaggregated. The increase in the volume of total exports reflects the effects of a good export policy. Economic literature has shown that export-oriented economic policies promote economic growth. In this case, the expected sign is positive

\section{- The active population (POPa)}

The population plays a vital role in increasing production. In addition to the fact that it is the labor force that implements the production activity, we can add that an increase in productivity reflects an increase in growth. The population therefore positively influences GDP growth (Fawaz Aminou, 2012).

\section{- Gross formation of fixed capital}

According to the Keynesian analysis, the growth of gross formation of fixed capital (GFCF) has a multiplier effect on income, that is the increase in investment leads to an increase in production, which leads to an increase in returns. Hence the expected sign is positive.

\section{- The exchange term}

The terms of trade index, which is the ratio of exports' prices as to import prices, is assumed to have a positive effect on economic growth to the extent that it is likely to make the domestic supply more dynamic, thus increasing the capacity of the economy to respond to foreign demand. The economic literature assumes that an improvement in the terms of trade increases foreign exchange earnings, national savings (Lezona, 2005). So the expected sign of this variable must be positive.

\section{- The degree of commercial openness:}

The degree of openness index is measured as the ratio of exports plus imports to GDP. It allows a country to open up in international trade in order to import goods that are beneficial to growth. An increase in this ratio should lead to an increase in growth (Nadia Lemzoudi, 2005). Hence the expected sign is positive. 


\subsection{Source and Data Processing}

The data used for the estimations come from the Bank of Central African States (BEAC) and the World Bank (WB). Data processing will be done using Microsoft Excel 2007 and STATA-14 software.

\section{Presentation and Analysis of the Results}

This section proceeds to the presentation of a descriptive and econometric analysis of our study.

\subsection{Results of the Descriptive Approach}

This subsection enables us to make a descriptive analysis of the different trends of each variable used in our study.

\subsubsection{Comparative Evolution of Non-Oil Exports and Non-Oil GDP 1985-2015}

This Figure below shows the comparative evolution between non-oil exports and non-oil GDP in the Republic of the Congo.

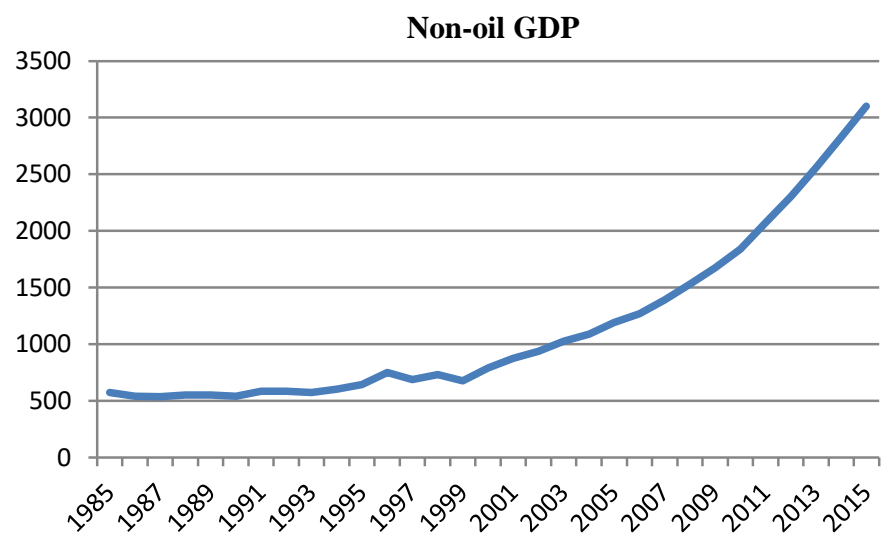

Figure 1. Evolution of non-oil GDP from 1985 to 2015

Source: Author from World Bank Data.

An analysis of this Figure shows that GDP is constantly changing over the period. It is noted that between 1997 and 2000, the non-oil GDP is trended downwards. This can be explained by the socio-political turmoil the country experienced during this period, which led to a slowdown in the economy. From 2000 to 2015 a steady growth in non-oil GDP was observed. This growth can be explained by several parameters: The return to peace; The introduction of structural adjustment policies that led to debt relief under the Enhanced Heavily Indebted Poor Countries (HIPC) Initiative. This situation has consequently led to a revival of activity in the non-oil sectors, particularly in agriculture and forestry, manufacturing industries, electricity, gas and water, construction and public works, transport, and telecommunications.

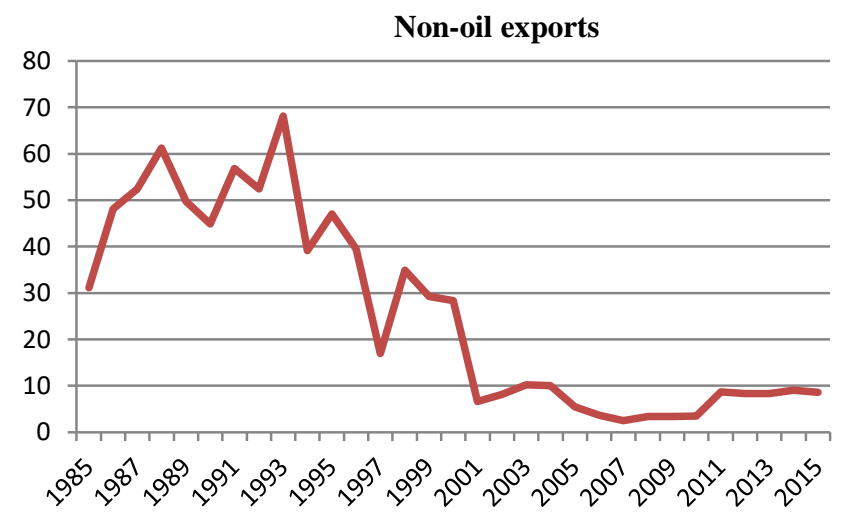

Figure 2. Evolution of Non-Oil Exports from 1985 to 2015

Source: Author from the statistics directory of BEAC. 
The analysis in this Figure shows the evolution of non-oil exports. In the light of this evolution, we find that the non-oil Exports sector has continually declined from 1985 to 2015, thus, narrowing down the productive base of the Congolese economy, but we nevertheless notice peaks in 1988 and in 1993.

The downward trend of this indicator can be explained on the first hand by the fact that the Congolese State has over the years gradually abandoned the non-oil sector to the detriment of the oil sector. On the other hand, from 2010 to 2015, we notice a slight increase in non-oil sector exports. This can be explained by debt cancellation through the completion point of the Heavily Indebted Poor Countries Initiative (HIPC), which has allowed foreign investors to invest in this sector and boost exports from this sector, also by the policies put in place by the government with the aim of diversifying the economy.

Based on the analysis of these two Figures above, we find that exports and non-oil GDP do not follow the same trend because, exports have a downward trend, while non-oil GDP has an upward trend. This rejects our original assumption that non-oil GDP and exports have an uptrend.

\subsection{Econometric Results}

This section presents the econometric and economic results of this study. It assesses the impact of exports in the Republic of Congo.

\subsubsection{Presentation of Econometric Results}

We will present the results of the econometric model that assesses the impact of exports on growth in Congo in the non-oil sector.

\subsubsection{Study of Stationarity of Series}

The series of our study are chronological or temporal. They must maintain a constant distribution over time. Hence the need of making them stationary through the stationarity test. A time series is said to be stationary if it has neither trend nor seasonality.

There are several stationarity tests, namely: the usual Dickey-Fuller root test (ADF) which can be simple or augmented, the Phillips Perron test and the Kwiatkowski, Phillips, Smidth, and Shin (KPSS) test.

In this work, we use the unit root test to examine this stationarity by performing level, first difference, or second difference regression.

The decision rule is written as follows:

- H0: presence of a unit root, that is to say, the series is nonstationary;

- H1: absence of a unit root, that is to say, the series is stationary

Referring to the tabulated values made using the Augmented Dickey-Fuller (ADF) test, we obtain at the 5\% threshold, the results recorded in the table below.

Table 1. Results of the stationarity test series

\begin{tabular}{ccccc}
\hline Variables & Degree of differentiation & ADF test statistics & Critical value (at the 5\% level) & Decision \\
\hline GDPno & Second difference & -4.055 & -3.000 & $\mathrm{I}(2)$ \\
EXPno & Second difference & -3.300 & -3.000 & $\mathrm{I}(2)$ \\
GFCF & Second difference & -3.345 & -3.000 & $\mathrm{I}(2)$ \\
EXCHt & Second difference & -3.939 & -3.000 & $\mathrm{I}(2)$ \\
POPa & Second difference & -2.864 & -2.994 & $\mathrm{I}(2)$ \\
\hline
\end{tabular}

Source: Author from Stata's result.

The results of the Augmented Dickey-Fuller (ADF) unit root test show that the endogenous variable and the exogenous variables are stationary in the second difference. We must differentiate them twice to make them stationary. 


\subsubsection{Cointegration Test}

Table 2. Regression of non-stationary variables

\begin{tabular}{|c|c|c|c|c|c|c|}
\hline Source & SS & df & MS & & Number of obs & $=31$ \\
\hline & & & & & $\mathrm{F}(4,26)$ & $=123.81$ \\
\hline Model & 9.0406199 & 4 & 2.26015497 & & Prob $>F$ & $=0.0000$ \\
\hline Residual & .474632331 & 26 & .01825509 & & R-squared & $=0.9501$ \\
\hline & & & & & AdjR-squared & $=0.9424$ \\
\hline Total & 9.51525223 & 30 & .317175074 & & RootMSE & $=.13511$ \\
\hline lnGDPno & Coef. & Std.Err. & $\mathrm{t}$ & $\mathrm{P}>|\mathrm{t}|$ & \multicolumn{2}{|c|}{ [95\%Conf.Interval] } \\
\hline $\operatorname{lnEXPno}$ & .1126071 & .0528777 & 2.13 & 0.043 & .0039156 & .2212987 \\
\hline lnEXCGt & .46319 & .0997182 & 4.64 & 0.000 & .2582163 & .06681637 \\
\hline LnGFCF & .0207678 & .0211006 & 0.98 & 0.334 & -.0226051 & .0641407 \\
\hline $\ln \mathrm{POPa}$ & 1.483792 & .179404 & 8.27 & 0.000 & 1.114927 & 1.852658 \\
\hline _cons & -16.78556 & 2.455742 & -6.84 & 0.000 & -21.83341 & -11.73771 \\
\hline
\end{tabular}

Table 3. Residual stationarity test

\begin{tabular}{ccccc}
\hline \multicolumn{2}{c}{ Dickey-Fuller test for unit root } & \multicolumn{3}{c}{ Number of obs $=30$} \\
\hline & & Interpolated Dickey-Fuller \\
\hline & TestStatistic & $1 \%$ CriticalValue & $5 \%$ CriticalValue & $10 \%$ CriticalValue \\
\hline
\end{tabular}

The stationarity test shows that the model residuals of the non-stationary variables are not stationary because the p-value is equal to 0.0956 which is much greater than $1 \%(0.01)$, so the series of our model are not cointegrated and we can not estimate the model with error correction. However, it is possible to study the autoregressive vector model (VAR) for which we determine the optimal delay number

Table 4. Correlogram of determination of optimal delay number

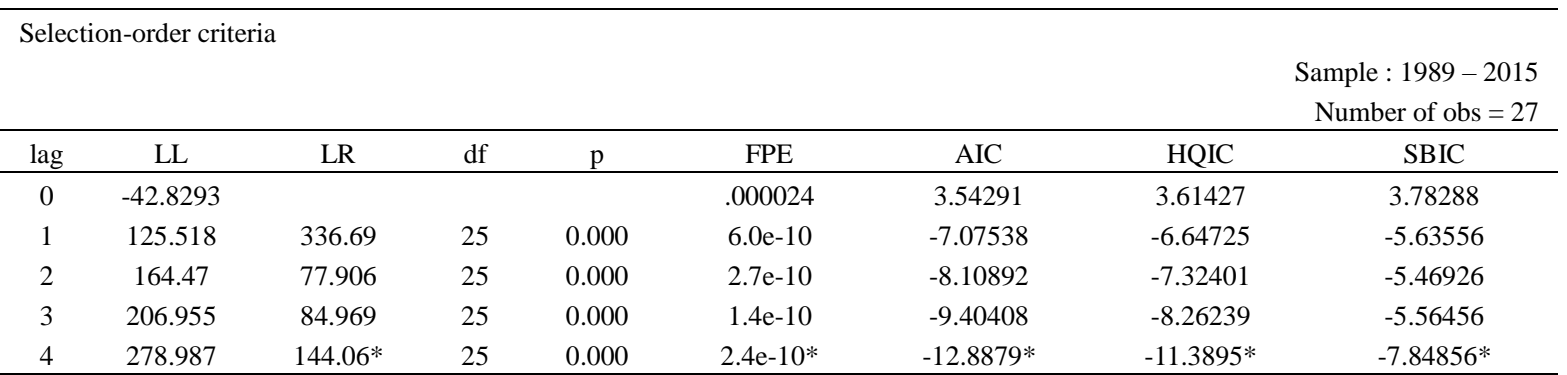

Endogenous: lnGDPno;lnEXPno; ln GFCF; In POPa.Exogenous: _cons.

It appears from this table that the maximum of the criteria that minimize the information related to the number of delays 4 . Therefore, the value 4 is considered to be the maximum number of delays of the VAR model.

Table 5. VAR model estimation

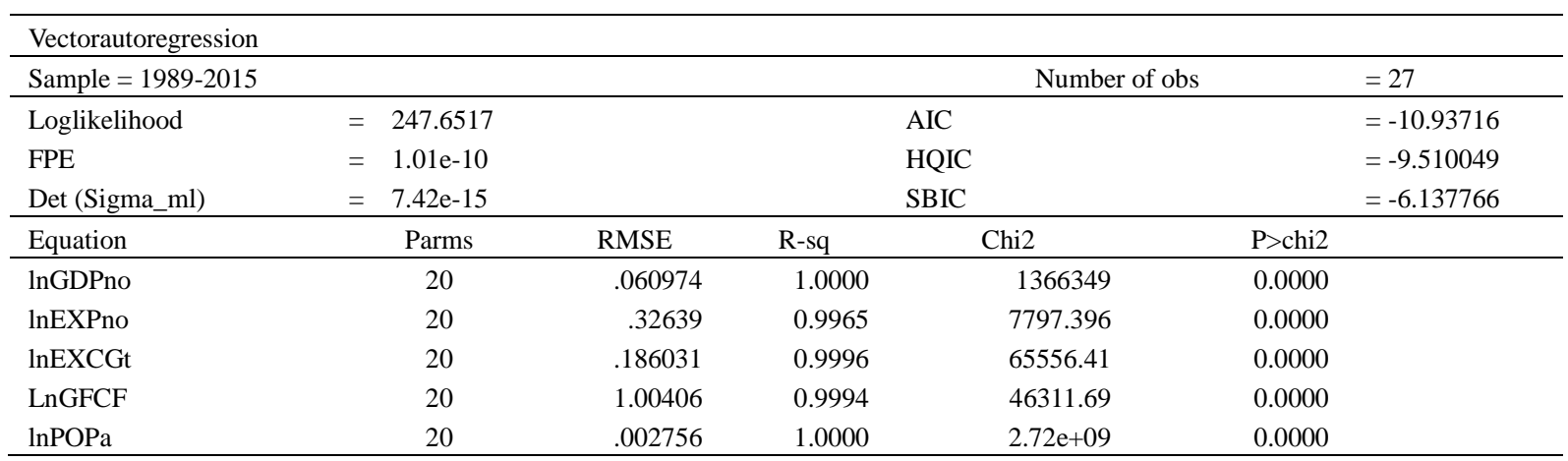




\begin{tabular}{|c|c|c|c|c|c|c|}
\hline & Coef. & Std.Err. & $\mathrm{z}$ & $\mathrm{P}>|\mathrm{z}|$ & \multicolumn{2}{|c|}{ [95\%Conf.Interval] } \\
\hline \multicolumn{7}{|l|}{ Ln GDPno } \\
\hline L.1. & .7072493 & .3006312 & 2.35 & 0.019 & .118023 & 1.296476 \\
\hline L.2. & -.3827563 & .3455014 & -1.11 & 0.268 & -1.059927 & .2944139 \\
\hline L.3. & -.0912989 & .2861733 & -0.32 & 0.750 & -.6521883 & .4695905 \\
\hline L. 4 . & .4175392 & .2579772 & 1.62 & 0.106 & -.0880868 & .9231653 \\
\hline \multicolumn{7}{|l|}{ Ln EXPno } \\
\hline L.1. & -.0562661 & .0361192 & -1.56 & 0.119 & -.1270585 & .0145263 \\
\hline L.2. & -.00789 & .0326619 & -0.24 & 0.809 & -.0719063 & .0561262 \\
\hline L.3. & .035434 & .0350245 & 1.01 & 0.312 & -.0332128 & .1040809 \\
\hline L. 4 . & -.0451425 & .0254839 & -1.77 & 0.076 & -.0950901 & .0048051 \\
\hline \multicolumn{7}{|l|}{ Ln EXCHt } \\
\hline L.1. & .0654341 & .0682708 & 0.96 & 0.338 & -.0683741 & .1992424 \\
\hline L.2. & -.0443678 & .0532116 & -0.83 & 0.404 & -.1486606 & .0599249 \\
\hline L.3. & .0412124 & .0643135 & 0.64 & 0.522 & -.0848397 & .1672645 \\
\hline L. 4 . & .052995 & .0674611 & 0.79 & 0.432 & -.0792263 & .1852163 \\
\hline \multicolumn{7}{|l|}{ Ln GFCF } \\
\hline L.1. & .0019585 & 0.115448 & 0.17 & 0.865 & -.020669 & .0245859 \\
\hline L. 2 . & .0020553 & .0146667 & 0.14 & 0.889 & -.026691 & .0308016 \\
\hline L. 3 . & -.0567188 & .0929187 & -0.61 & 0.542 & -.2388361 & .1253985 \\
\hline L. 4 . & .1698408 & .0750769 & 2.26 & 0.024 & .0226928 & .3169888 \\
\hline \multicolumn{7}{|l|}{ Ln POPa } \\
\hline L.1. & -11.14652 & 6.0344 & -1.85 & 0.065 & -22.97373 & .6806829 \\
\hline L.2. & 8.191065 & 8.30819 & 0.99 & 0.324 & -8.092689 & 24.47482 \\
\hline L. 3 . & 2.44321 & 10.76581 & 0.23 & 0.820 & -18.65738 & 23.5438 \\
\hline L. 4 . & .5296195 & 5.143172 & 0.10 & 0.918 & -9.550813 & 10.61005 \\
\hline
\end{tabular}

\subsubsection{Interpretation of Results}

Regarding the non-oil GDP (non-oil gross domestic product) variable, the analysis of the results shows that non-oil GDP lagged by one year, (L1) is significant at the 5\% level and has a positive impact on current GDP.

When non-oil GDP increased by $1 \%$, the current GDP increases by $0.70 \%$. The positive impact of non-oil GDP can be explained by the fact that GDP is an indicator of growth that gives a global picture of an economy, and shows very good performance in terms of GDP, plus a country reinforces its credibility and stimulates its attractiveness this also increases its economic productivity

Non-oil Exports, delayed by 4 years (L4), is significant at the $10 \%$ level and has a negative impact on current GDP. When exports increase by $1 \%$, the non-oil GDP decreases by $-0.045 \%$. Exports are an important part of the country's growth. They contribute more than $80 \%$ of the total revenue of the State. The negative impact is explained by the fact that non-oil exports do not stimulate investment, which in his turn does not promote economic growth because they contribute only $20 \%$ of government revenue. Yet Congo has enormous economic potentialities that remain under-exploited because of its strong dependence on a single product, oil. However, the export of this cash crop depends on world demand and international prices are exogenous from Congo's economic policy. Business prospects are therefore limited. The Congo could only withstand external shocks if there is diversification of exports, this is not the case today. Oil could not be seen in isolation from the rest of the economy. Revenues from natural resources could help take off from other sectors and provide Congo with a variety of infrastructure to support economic take-off. In return, the other sectors, once developed, would reduce the country's dependence on the oil sector.

The Gross Formation of Fixed Capital variable is delayed by 4 years (L4) is significant at the $5 \%$ threshold. This variable has a positive impact on current GDP. When GFCF increases by $1 \%$, the non-oil GDP increased by $0.16 \%$. According to some authors, investment is a very important determinant of economic growth. The Gross Formation of Fixed Capital, formerly known as gross domestic investment, refers to expenditures made for the purpose of increasing the fixed assets of the economy.

The investment is significant and correlates positively with income. This variable presents the expected sign through its coefficient. The GFCF variable is, therefore, an important determinant for economic growth in the Congo. The accumulation of capital favors Congolese production in the sense that capital enters into the creation of wealth. This result confirms the theory that investment is vital to the economy. But we can see that this contribution to the evolution of GDP is weak. Indeed, the $1 \%$ increase in investment leads to nothing but a $0.16 \%$ increase in GDP. This is explained by the low standard of living of the population and their difficulty in saving or 
investing as their daily problems absorb their entire economy. One could also emphasize the low contribution of the State in agricultural activities. The state could be more involved in encouraging and improving production.

Labor force: this variable is significant at the $10 \%$ threshold when it is delayed by one year (L1) and has a negative impact on current GDP. When the Labor Force increases by $1 \%$, non-oil GDP decreases by $-0.11 \%$.

\section{Conclusion}

The objective of our study was to evaluate the impact of exports on economic growth in Congo Brazzaville in the non-oil sector. To achieve this objective, we made a descriptive analysis of some variables and an econometric analysis as well.

The descriptive analysis enabled us to prove our first hypothesis. And this assumption has not been verified because the two variables (non-oil GDP and non-oil exports) do not look the same.

Regarding the econometric analysis, data from our study covering the period of 1985-2015 were used to estimate the model (VAR) to identify the impact of exports on growth in Congo. The results show that exports have a negative and significant impact on economic growth. In fact, because of the high dependence on a single product, this constitutes an obstacle to the development of other sectors of activities and a brake to the diversification of the economy and the reduction of poverty.

\section{References}

Akilou, A. (2009). Analyse des effets des exportations sur la croissanceéconomique du Togo. Revue Africaine de l'Intégration, 3(2), 22.

Balassa, B. (1978). Export and economic growth further evidence. Journal of Development Economics, 5, 181-189. https://doi.org/10.1016/0304-3878(78)90006-8Get

Brunnshweiler, C. (2008). Cursing the Blessings? Natural Ressource Abundance, Institutions, and Economic growth. World Development, 36, 399-419. https://doi.org/10.1016/j.worlddev.2007.03.004

Brunnshweiler, C., \&Bulte, E. (2009). Natural ressources and violent conflict: Ressource abundance, dependance, and the onset of civil wars. Oxford Economic Papers, 61(4), 651-674. https://doi.org/10.1093/oep/gpp024

Fawaz, A. (2012). AdéchinanAminou, Analyse des effets des eportations de biens sur la croissance et le developpementhumain au Bénin 2012 (Thesis, p. 42).

Lezona, H. (2005). Impact des exportations sur la croissanceéconomique au Congo (Thesis, p. 95). Brazzaville, IDEP, 2005.

Michaely, M. (1977). Exports and growth: An empirical investigation. Journal of Development Economics, 4, 49-54. https://doi.org/10.1016/0304-3878(77)90006-2

Nadia, L. (2005). L'impact du degréd'ouverture sur la croissanceéconomique: Cas de six pays d'Afrique de l'ouest (Thesis, p. 18).

Saminira, A., \& Adamson, R. (2013). Exportation, croissanceéconomique et integration regionale: La relation entre exportation et croissanceéconomique à Madagascar, Centre de Recherche, d'Etudes et d'Appui à l'AnalyseEconomique à Madagascar (CREAM), cahier n 16, p. 27.

Snyder, R. (2006). Does lootable wealth Bead Disorder? Comparative Political Studies, 39, 943-968. https://doi.org/10.1177/0010414006288724

Subassat, T. (2002). Does Export Promotion Increase Economic Growth? Some Cross-Section Evidence. Development Policy Review, 20, https://doi.org/10.1111/1467-7679.00175

Syrquin, \& Chenery. (1989). Mondialisation, une chance pour l'environnement, 1989, Washington DC.https://doi.org/10.1093/wber/3.2.145

Tyler, W. G. (1981). Growth and export expansion in developing countries: Some empirical evidence. Journal of Development Economics, 9(1), 121-130. https://doi.org/10.1016/0304-3878(81)90007-9

\section{Copyrights}

Copyright for this article is retained by the author(s), with first publication rights granted to the journal.

This is an open-access article distributed under the terms and conditions of the Creative Commons Attribution license (http://creativecommons.org/licenses/by/4.0/). 